\title{
Changing indications and techniques for corneal transplantations at a tertiary referral center in Turkey, from I 995 to 2014
}

This article was published in the following Dove Press journal:

Clinical Ophthalmology

I June 2016

Number of times this article has been viewed

\author{
Yesim Altay \\ Ayse Burcu \\ Gozde Aksoy \\ Evin Singar Ozdemir \\ Firdevs Ornek \\ Department of Ophthalmology, \\ Ankara Training and Research \\ Hospital, Ankara, Turkey
}

Correspondence: Yesim Altay

Department of Ophthalmology, Ankara

Training and Research Hospital,

48, Cadde No 33/3। Cukurambar,

06520 Ankara, Turkey

Tel +905324902298

Email altayye@yahoo.com
Background: Indications for corneal transplantation in developed and developing nations differ according to the different spectrum of corneal disease in each country.

Objective: The purpose of this study is to analyze the changing indications and surgical techniques for corneal transplantation over the past 20 years at a tertiary referral center in Turkey. Methods: We retrospectively reviewed the records of patients who underwent keratoplasty from January 1995 to December 2014 (between 1995 and 2004, period 1, and between 2005 and 2014, period 2). Patients' demographic data, indications for corneal transplantation, and the type of surgery were recorded.

Results: The number of keratoplasties performed ranged from 548 in period 1 to 782 in period 2. Between 1995 and 2004, the leading indications were keratoconus (34.1\%), bullous keratopathy (17\%), and non-herpetic corneal scar (13.3\%), and between 2005 and 2014, they were keratoconus (33.8\%), corneal stromal dystrophy (14.2\%), and bullous keratopathy (12.7\%). All the keratoplasties performed in the 1995-2004 period were penetrating keratoplasty (PKP). During the period 2005-2014, PKP accounted for 93\%, automated lamellar keratoplasty 5.8\%, and deep anterior lamellar keratoplasty $1.2 \%$ of all corneal transplantations.

Conclusion: Keratoconus was the leading indication for keratoplasty in both periods. In the 2005-2014 period, corneal stromal dystrophy increased significantly. All the keratoplasties performed in period 1 and $93 \%$ of all keratoplasties performed in period 2 were PKP.

Keywords: corneal transplantation, indication, keratoconus, keratoplasty technique, penetrating keratoplasty

\section{Introduction}

Corneal transplantation remains the most common tissue transplantation performed worldwide. Avascularity and immunologic privilege of the cornea allow greater success rates of corneal transplants in comparison with other organ transplants. ${ }^{1}$

After Zirm performed the first successful penetrating keratoplasty (PKP) in 1905, advancements in sutures, antibiotics, corticosteroids, operating microscopes, and eye banking improve the surgical outcomes in subsequent century. ${ }^{2}$

The indications of corneal transplantation in developed and developing nations differ according to the different spectrum of corneal disease in each country. Studies from USA and Canada have documented that pseudophakic bullous keratopathy (PBK) and regraft are the leading indications for keratoplasty. ${ }^{3-7}$ Reports from Iran, New Zealand, and Israel suggest that keratoconus is the most frequent indication for corneal transplantation, ${ }^{8-11}$ while in India and the People's Republic of China, postinfectious corneal scar and traumatic corneal scar are the major indications. ${ }^{12-14}$ 
Because the leading indications for corneal transplantation and preferred surgical techniques are changing across different regions and time, up-to-date examinations of these trends are important to anticipate future changes in the field.

The aim of this study is to analyze the trends in major indications and surgical techniques for corneal transplantation at the Eye Bank of Ankara Training and Research Hospital, a tertiary referral center in Turkey.

\section{Materials and methods}

Medical records of 1,330 patients who underwent corneal transplantation at the Eye Bank of Ankara Training and Research Hospital between January 1995 and December 2014 were retrospectively reviewed. Patients provided written consent for surgery, including the use of patient information for future studies. This Eye Bank is the cornea provider for the whole city. In this study, the principles of the Declaration of Helsinki were followed. Ethical approval was not sought from the Institutional Review Board of our hospital because patients provided written consent for surgery, including the use of patient information for future studies. Each patient's demographic data, keratoplasty indications, and surgical techniques were recorded. The records were analyzed with respect to the clinical indications for corneal transplantation and keratoplasty techniques. The study period was divided into two, January 1995 to December 2004 (period 1) and January 2005 to December 2014 (period 2), for descriptive and analytical purposes.

The indications for corneal transplantation were divided into nine diagnostic categories: keratoconus, bullous keratopathy (BK), non-herpetic infectious corneal scar (fungal, bacterial, Acanthamoeba), herpetic corneal scar, traumatic corneal scar, regraft, stromal corneal dystrophy, endothelial dystrophy, corneal hereditary endothelial dystrophy. When multiple transplantations were performed, the diagnosis was considered to be regraft regardless of the initial indication for transplantation. The BK was subgrouped as aphakic BK (ABK) and PBK. In the cases of PBK, the types of intraocular lens (IOL) were also recorded. Results were obtained by the analysis of the type of surgical techniques used, clinical indications for corneal transplantation, and the year in which surgery was performed.

We used Statistical Package for Social Sciences Version 15.0 for statistical evaluation. We compared the differences in frequencies of indications between the two time periods (1995-2004 versus 2005-2014) by using chisquare test. A $P$-value $<0.05$ was considered statistically significant.
Table I Patients' demographic characteristics

\begin{tabular}{|c|c|c|}
\hline \multirow[t]{2}{*}{ Characteristics } & \multicolumn{2}{|l|}{ Periods } \\
\hline & $1995-2004(n=548)$ & $2005-2014(n=782)$ \\
\hline $\begin{array}{l}\text { Age (years) mean } \pm \mathrm{SD} \text {, } \\
\text { (range) }\end{array}$ & $38.49 \pm 19.70(5-90)$ & $42.07 \pm 18.42(7-88)$ \\
\hline Female & $220(40.1 \%)$ & $32 \mid(4 \mid \%)$ \\
\hline Male & $328(59.9 \%)$ & 461 (59\%) \\
\hline
\end{tabular}

Abbreviation: SD, standard deviation.

\section{Results}

A total of 1,330 corneal transplantation cases were included in this study. The mean age was $40.59 \pm 19.03$ years (range: 5-90 years). There were 540 females $(40.7 \%)$ and 789 males (59.3\%). The distribution of patients' demographic data is shown in Table 1.

The most common indication for corneal transplantation in the 1995-2004 period (548 transplants) was keratoconus $(\mathrm{n}=187,34.1 \%)$. The second most common diagnosis was BK (PBK and ABK; $n=93,17 \%$ ), followed by non-herpetic corneal infectious scar $(n=73,13.3 \%)$, traumatic corneal scar $(n=70,12.8 \%)$, herpetic corneal scar $(n=67,12.2 \%)$, regraft $(n=24,4.4 \%)$, stromal dystrophy $(n=23,4.2 \%)$, and endothelial dystrophy $(n=4,0.7 \%)$.

The leading indication for corneal transplantation for the past decade (2005-2014, 782 transplants) was also keratoconus ( $n=264,33.8 \%)$, and other indications in declining order were stromal dystrophy $(n=111,14.2 \%)$, BK $(n=99$, $12.7 \%)$, herpetic corneal scar $(n=90,11.5 \%)$, traumatic corneal scar $(n=66,8.4 \%)$, non-herpetic infectious corneal scar $(n=58,7.4 \%)$, regraft $(n=53,6.8 \%)$, and endothelial dystrophy $(n=23,2.9 \%)$. The indications for keratoplasties in two periods are shown in Table 2 and Figure 1.

The number of corneal transplantation in the 2005-2014 period $(n=782)$ was more than the number of corneal transplantation in the 1995-2004 period $(n=548)$. During the 1995-2004 period, all the donor cornea tissues were domestic. In the past 2 years, corneal tissue became more available in our center with both domestic and imported corneas, and during this period, 182 corneal transplantations were performed by using imported cornea (Eye Bank Association of America - distributed corneal tissue).

The proportion of keratoconus as the most common indication was almost the same in both periods: $34.1 \%$ and $33.8 \%$, respectively. BK, which comprised $17.0 \%$ of patients in period 1 , had a statistically significant decrease to $12.7 \%$ $(P=0.001)$ in period 2. In the bullous group, PBK with anterior chamber IOL was decreased from $6.6 \%$ to $4.3 \%$ and ABK was decreased from $4.6 \%$ to $2.6 \%$ in the $2005-2014$ period, while the percentage of PBK with posterior chamber IOL was the same. Statistically more significant increase was detected 
Table 2 Indications for corneal transplantation from 1995 to 2014 with 10-year interval

\begin{tabular}{|c|c|c|c|c|}
\hline Diagnosis & I995-2004; n (\%) & 2005-20I4; n (\%) & Overall; n (\%) & $P$-value \\
\hline Keratoconus & $187(34.1)$ & $264(33.8)$ & 45I (33.9) & 0.89 (NS) \\
\hline BK & $93(16.97)$ & $99(12.65)$ & $192(14.43)$ & $0.02 *$ \\
\hline Aphakic BK & $25(4.6)$ & $20(2.6)$ & $45(3.38)$ & \\
\hline Pseudophakic BK with anterior IOL & $36(6.6)$ & $34(4.3)$ & $70(5.26)$ & \\
\hline Pseudophakic BK with posterior IOL & $32(5.8)$ & $45(5.8)$ & $77(5.78)$ & \\
\hline Non-herpetic infectious corneal scar & $73(13.3)$ & $58(7.4)$ & $|3|(9.84)$ & $0.0003^{*}$ \\
\hline Herpetic corneal scar & $67(12.2)$ & $90(11.5)$ & $157(\mid 1.8)$ & 0.68 (NS) \\
\hline Traumatic corneal scar & $70(12.8)$ & $66(8.4)$ & $136(10.22)$ & $0.01 *$ \\
\hline Stromal dystrophy & $23(4.19)$ & $111(14.19)$ & $134(10.07)$ & $0.0001 *$ \\
\hline Macular dystrophy & $14(2.6)$ & $75(9.6)$ & $89(6.69)$ & \\
\hline Lattice dystrophy & $5(0.9)$ & $20(2.6)$ & $25(1.87)$ & \\
\hline Granular dystrophy & $4(0.7)$ & $16(2.0)$ & $20(1.5)$ & \\
\hline Regraft & $24(4.4)$ & $53(6.8)$ & $77(5.78)$ & 0.06 (NS) \\
\hline GF due to other pathologies & $15(2.8)$ & $33(4.2)$ & $48(3.6)$ & \\
\hline GF due to rejection & $9(1.6)$ & $20(2.6)$ & $29(2.18)$ & \\
\hline Endothelial dystrophy & $4(0.7)$ & $23(2.94)$ & $27(2.0)$ & $0.004 *$ \\
\hline Fuchs' endothelial dystrophy & $\mathrm{I}(0.2)$ & $15(1.9)$ & $16(1.2)$ & \\
\hline CHED & $3(0.5)$ & $8(1.0)$ & II (0.8) & \\
\hline Other & $7(1.3)$ & $18(2.3)$ & $25(1.8)$ & 0.17 (NS) \\
\hline Total & $548(100)$ & $782(100)$ & $1,330(100)$ & \\
\hline
\end{tabular}

Notes: *Statistically significant difference, $\chi^{2}$. NS, not statistically significant difference, $\chi^{2}$.

Abbreviations: BK, bullous keratopathy; GF, graft failure; CHED, corneal hereditary endothelial dystrophy; IOL, intraocular lens.

for stromal dystrophy which increased from $4.2 \%$ to $14.2 \%$ in the last period $(P=0.0001)$. Non-herpetic infectious corneal scar and traumatic corneal scar showed a significant decrease to $7.4 \%$ and $8.4 \%$, respectively $(P=0.001)$, in period 2 . No statistically significant differences were detected for herpetic corneal scar (from $12.2 \%$ to $11.5 \%$ ) and regraft (from $4.4 \%$ to $6.8 \%$ ) between two periods ( $P=0.68$ and $P=0.06$, respectively). Endothelial dystrophy (from $0.2 \%$ to $2.9 \%$ ) rates showed a significant increase $(P=0.004)$ in the past decade (Table 2, Figure 1).

All the regrafts in our study were because of secondary graft failure. A total of $37.5 \%$ of graft failure was due to graft rejection and $62.5 \%$ of graft failure was due to other pathologies (recurrence of primary diseases, graft ulcer, ocular surface defect, glaucoma, and late endothelial failure) in period 1 . This distribution was almost the

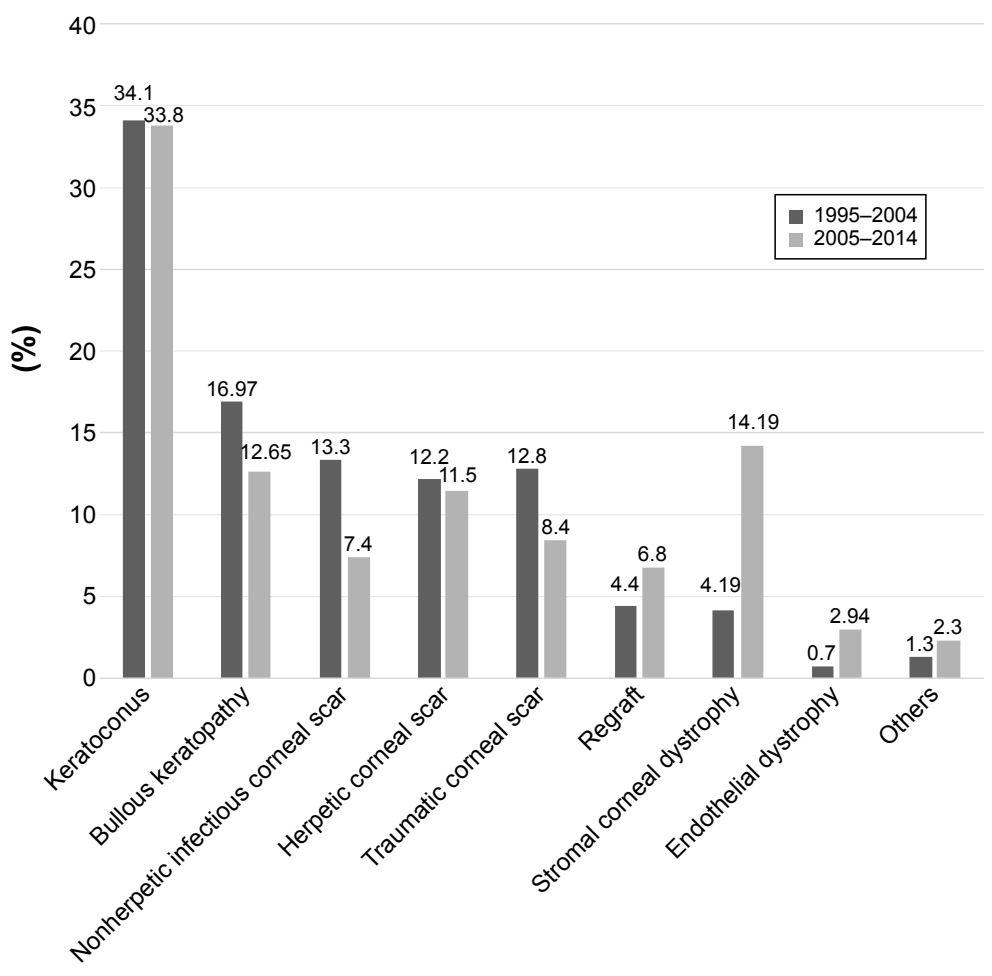

Figure I Indications for corneal transplantation from 1995 to 2014 at a tertiary referral center in Turkey. 
Table 3 Initial diagnoses of patients with regraft

\begin{tabular}{|c|c|c|c|c|}
\hline \multirow[t]{2}{*}{ Initial diagnosis } & \multicolumn{2}{|l|}{$1995-2004$ regraft $(n=24)$} & \multicolumn{2}{|l|}{$2005-2014$ regraft $(n=53)$} \\
\hline & GF due to other pathologies $(n=15)$ & $\begin{array}{l}\text { GF due to } \\
\text { rejection }(n=9)\end{array}$ & $\begin{array}{l}\text { GF due to other } \\
\text { pathologies }(n=33)\end{array}$ & $\begin{array}{l}\text { GF due to } \\
\text { rejection }(n=20)\end{array}$ \\
\hline Keratoconus & 5 (graft ulcer $=3$, glaucoma $=2$ ) & 1 & $\begin{array}{l}\text { I2 }(\text { late endothelial failure }=2, \\
\text { graft ulcer }=6, \text { glaucoma }=4)\end{array}$ & 9 \\
\hline Aphakic BK & 2 (glaucoma $=2$ ) & I & 2 (glaucoma $=1$, graft ulcer $=I$ ) & 2 \\
\hline $\begin{array}{l}\text { Pseudophakic BK with } \\
\text { posterior IOL }\end{array}$ & I (persistent epithelial defect $=\mathrm{I})$ & - & $\begin{array}{l}3(\text { glaucoma }=2, \text { persistent } \\
\text { epithelial defect }=I)\end{array}$ & - \\
\hline Herpetic corneal scar & 3 (recurrence of herpetic keratitis $=3$ ) & I & $\begin{array}{l}6 \text { (recurrence of herpetic } \\
\text { keratitis }=4 \text {, glaucoma }=I \text {, } \\
\text { persistent epithelial defect }=I \text { ) }\end{array}$ & 5 \\
\hline Non-herpetic corneal scar & I (graft ulcer $=$ I) & 2 & $\begin{array}{l}4 \text { (graft ulcer }=2, \text { glaucoma }=I, \\
\text { late endothelial failure }=I)\end{array}$ & I \\
\hline Traumatic corneal scar & 2 (late endothelial failure $=I$, glaucoma $=\mathrm{I}$ ) & 4 & $\begin{array}{l}2 \text { (traumatic wound } \\
\text { dehiscence }=I \text {, late graft } \\
\text { failure }=I \text { ) }\end{array}$ & I \\
\hline Stromal dystrophy & I (traumatic wound dehiscence $=\mathrm{I})$ & - & $\begin{array}{l}3 \text { (persistent epithelial } \\
\text { defect }=I \text {, traumatic wound } \\
\text { dehiscence }=I, \text { glaucoma }=I \text { ) }\end{array}$ & 2 \\
\hline CHED & - & - & $\begin{array}{l}\text { I (traumatic wound } \\
\text { dehiscence }=I)\end{array}$ & - \\
\hline
\end{tabular}

Abbreviations: BK, bullous keratopathy; CHED, corneal hereditary endothelial dystrophy; GF, graft failure; IOL, intraocular lens.

same in period $2(37.7 \%$ due to graft rejection, $62.3 \%$ due to other pathologies). The initial diagnoses and causes of graft failure of patients with regraft are shown in Table 3.

All the $548(100 \%)$ keratoplasties were PKPs in the 1995-2004 period. The distribution of techniques of corneal transplantations performed in the 2005-2014 period was as follows: 727 (93\%) PKPs, 46 (5.8\%) automated lamellar keratoplasties (ALKs), and nine (1.2\%) deep anterior lamellar keratoplasties (DALKs).

\section{Discussion}

We reported the clinical indications for and trends in corneal transplantation at a tertiary referral center in Turkey during the 20-year period, from January 1995 to December 2014. To the best of our knowledge, this is the first study of this type in Turkey. In this study, demographic data of transplant patients were very similar in both decades. The mean age was $40.59 \pm 19.03$ years, which is younger than that reported from Canada (69 years) and UK (56 years). ${ }^{6,15}$ This may reflect the fact that almost $34 \%$ of the keratoplasty procedures in our center were for keratoconus. We performed a literature review to identify similar studies that reported indications for corneal transplantation and surgical trends in different countries. A different frequency of indications for corneal transplantation has been reported in these studies (Table 4).
In our study, keratoconus (34\%) was the leading indication for corneal transplantation during both periods (1995-2004 and 2005-2014). However, in the USA and Canada, keratoconus was the third (15\%) and the fourth (16\%) most common indication for corneal transplants. ${ }^{3,4}$ But, it was the most common indication for keratoplasty in some other countries such as Iran, West Scotland, Germany, New Zealand, and Israel. ${ }^{8,10,11,20,21}$ There is no report on the prevalence of keratoconus in Turkey, but the high rate of keratoconus for keratoplasty may be explained with environmental and genetic factors. The association of vernal keratoconjunctivitis with keratoconus may be another contributing factor, because vernal keratoconjunctivitis shows high incidence in Turkey as in Iran and Israel. ${ }^{8,11}$ Insufficient use of collagen cross-linking treatment and infrequent use of specialized contact lens fitting may lead to earlier surgery for keratoconus in Turkey.

During the past decade, in our study, the rate of BK decreased from $17 \%$ to $12.7 \%$, as it was also reported in other studies. ${ }^{11,16,20-23}$ Although the percentage of ABK and PBK with anterior chamber IOL was decreasing significantly in the past decade, the percentage of PBK with posterior chamber IOL remained the same. This decrease in BK in our study was probably secondary to the advancements in cataract surgery techniques with which fewer patients were left aphakic to the quality of the implanted IOLs and to the use of viscoelastics during cataract surgery. 
Table 4 Summary of publications from different countries on indications for corneal transplantation published since 2005

\begin{tabular}{|c|c|c|c|c|c|c|c|}
\hline \multirow[t]{2}{*}{ References } & \multirow{2}{*}{$\begin{array}{l}\text { Year } \\
\text { published }\end{array}$} & \multirow{2}{*}{$\begin{array}{l}\text { Years } \\
\text { studied }\end{array}$} & \multirow[t]{2}{*}{ Country } & \multicolumn{3}{|c|}{ Leading indications } & \multirow{2}{*}{$\begin{array}{l}\text { Surgical } \\
\text { techniques used }\end{array}$} \\
\hline & & & & Ist & 2nd & 3rd & \\
\hline $\begin{array}{l}\text { Yaholom } \\
\text { et al" }\end{array}$ & 2005 & $|96|-2000$ & Israel & Keratoconus & Regraft & PBK & PKP \\
\hline $\begin{array}{l}\text { Darlington } \\
\text { et } \mathrm{al}^{3}\end{array}$ & 2006 & 1980-2004 & USA & PBK & Keratoconus & $\begin{array}{l}\text { Primary endotheliopathies } \\
\text { (Fuchs') }\end{array}$ & PKP \\
\hline $\begin{array}{l}\text { Dorrepaal } \\
\text { et } \mathrm{al}^{5}\end{array}$ & 2007 & 1996-2004 & Canada & Regraft & PBK & Fuchs' & PKP \\
\hline Kanavi et $\mathrm{al}^{8}$ & 2007 & 1994-2004 & Iran & Keratoconus & Corneal scar & PBK & PKP \\
\hline Xie et $\mathrm{al}^{14}$ & 2007 & $1997-2002$ & North China & $\begin{array}{l}\text { Non-herpetic } \\
\text { infectious scar }\end{array}$ & $\begin{array}{l}\text { Herpetic } \\
\text { corneal scar }\end{array}$ & Corneal scar & PKP \\
\hline $\begin{array}{l}\text { Siganos } \\
\text { et al }{ }^{16}\end{array}$ & 2010 & $1982-2006$ & Greece & BK & Keratoconus & Regraft & PKP \\
\hline $\begin{array}{l}\text { Boimer } \\
\text { et a }\left.\right|^{6}\end{array}$ & 2011 & 2000-2009 & Canada & PBK & Regraft & Fuchs' & PKP, DSAEK \\
\hline Zare et $\mathrm{al}^{9}$ & 2010 & 2004-2007 & Iran & Keratoconus & BK & $\begin{array}{l}\text { Non-herpetic corneal } \\
\text { scar }\end{array}$ & PKP, DALK, ALK \\
\hline Wang et al ${ }^{17}$ & 2011 & $2005-2010$ & $\begin{array}{l}\text { People's Republic } \\
\text { of China }\end{array}$ & $\begin{array}{l}\text { Infectious } \\
\text { corneal scar }\end{array}$ & $\begin{array}{l}\text { Herpetic } \\
\text { corneal scar }\end{array}$ & Keratoconus & PKP \\
\hline $\begin{array}{l}\text { Cunningham } \\
\text { et al }{ }^{10}\end{array}$ & 2012 & $2000-2009$ & New Zealand & Keratoconus & Regraft & BK & PKP, DALK, DSAEK \\
\hline $\begin{array}{l}\text { Keenan } \\
\text { et al }\left.\right|^{18}\end{array}$ & 2012 & 1999-2009 & UK & $\begin{array}{l}\text { Endothelial } \\
\text { graft failure }\end{array}$ & Keratoconus & Regraft & $\begin{array}{l}\text { PKP, endothelial } \\
\text { keratoplasty, DALK }\end{array}$ \\
\hline Pan et $\mathrm{al}^{13}$ & 2012 & 1999-2009 & $\begin{array}{l}\text { People's Republic } \\
\text { of China }\end{array}$ & $\begin{array}{l}\text { Herpetic } \\
\text { corneal scar }\end{array}$ & $\begin{array}{l}\text { Traumatic } \\
\text { corneal scar }\end{array}$ & Keratoconus & PKP \\
\hline Galvis et al ${ }^{19}$ & 2013 & 2004-20II & Colombia & PBK & Corneal scar & Active infectious keratitis & PKP, DSAEK \\
\hline Dasar et al ${ }^{12}$ & 2013 & $2002-2012$ & India & Corneal scar & Regraft & Spheroidal degeneration & PKP \\
\hline Ting et $\mathrm{al}^{20}$ & 2015 & $200 I-2010$ & West of Scotland & Keratoconus & Regraft & Fuchs' & $\begin{array}{l}\text { PKP, lamellar } \\
\text { keratoplasty }\end{array}$ \\
\hline
\end{tabular}

Abbreviations: ALK, automated lamellar keratoplasty; BK, bullous keratopathy; DALK, deep anterior lamellar keratoplasty; DSAEK, Descemet's stripping automated endothelial keratoplasty; PBK, pseudophakic bullous keratopathy; PKP, penetrating keratoplasty.

Non-herpetic keratitis scar showed a significant decrease in the 2005-2014 period (from $13.3 \%$ to $7.4 \%, P=0.0003$ ). Herpetic corneal scar also decreased in this period, but the difference was not significant (from $12.2 \%$ to $11.5 \%$, $P=0.68)$. Similar decreases were reported in a number of other studies, which were probably due to the improvement in antimicrobial treatment. ${ }^{11,16}$ But in some other countries such as India and North China, microbial corneal scar remained as a leading indication for keratoplasty. ${ }^{12,14}$

Although the diagnosis of corneal stromal dystrophy is less prevalent in many studies throughout the world, it was the second most common indication (14.2\%) for keratoplasty in our study during the past decade. ${ }^{4,5,7,10,13}$ In comparison with first 10-year of our study, the frequency of keratoplasties for stromal dystrophy (predominantly macular dystrophy) increased even more significantly $(P=0.0001)$ in the past 10 -year period. Factors that influence this rate may be inheritance due to consanguineous marriage that is common in Turkey and a referral bias since this study was performed in a tertiary referral hospital.
Because of progressively increasing number of corneal transplantations, regrafts remained one of the two leading indications in USA and Canada. ${ }^{5,6,10,11}$ In this study, despite slow increase in the past decade $(4.4 \%-6.8 \%, P=0.06)$, regraft was not in top five keratoplasty indications in both periods. The percentage of graft failure due to graft rejection was almost the same in both the periods. Graft ulcer, glaucoma, and recurrence of herpetic keratitis were the three main causes of graft failure unrelated to allograft rejection in both periods. Several factors contributed to the low regraft rate in our study. First, because of the shortage of corneal tissues in Turkey, patients who have the best chance of graft success were preferred for corneal transplantation to provide improved vision. Second, because of socioeconomic factors and long postoperative treatment period, some patients were reluctant to regraft when the grafts became opaque.

Because of high prevalence of keratoconus and macular dystrophy and low prevalence of regraft and Fuchs' dystrophy (which is relatively rare in the Middle East and Mediterranean region ${ }^{9,11,23}$ ), in our study, top five indications 
for corneal transplantation will continue to be different from USA and Europe. Genetic and environmental factors, waiting list of surgical cases, and increased availability of corneal tissue with imported corneas (Eye Bank Association of America - distributed cornea) in the 2005-2014 period may be a contributing factor to the change of indications for corneal transplantation in this study.

During the past decade of the study, we noticed small changes in transplantation techniques. Although the total number was small, only 55 (7\%) lamellar surgeries were performed in this period, there was an increasing trend in the number of lamellar keratoplasties (ALK and DALK) for mainly keratoconus and anterior corneal scars. This shift toward lamellar keratoplasty techniques is small but similar to the changing trends reported in other countries. ${ }^{6,7,10,17,18,20,22}$ ALK and DALK have advantages over traditional PKP, including the preservation of host endothelium (eliminating endothelial rejection), reduced operative risk from essentially closed globe procedure, and potentially faster visual recovery. ${ }^{20,24}$ However, compared with ALK, DALK has some difficulties such as: it is a highly skill-demanding procedure and it has a longer surgical time with a high probability of conversion to PKP in the case of Descemet membrane perforation. ${ }^{19}$

\section{Conclusion}

Keratoconus was the most common indication for corneal transplantation in our center, which is different from most developed countries where regraft, BK, and Fuchs' endothelial dystrophy were the main indications. ${ }^{3-7}$ PKP was the most preferred corneal transplant technique in the total study period. However, there has been a significant shift to the use of ALK and DALK, especially for keratoconus and anterior corneal pathologies in the past decade, similar to other studies. ${ }^{6,7}$ Because the leading indications for corneal transplantation and preferred surgical techniques are changing across different regions and time, up-to-date studies from different locations are necessary to detect the changes to predict future trends in the field.

\section{Disclosure}

The authors report no conflicts of interest in this work.

\section{References}

1. Ple-Plakon PA, Shtein RM. Trends in corneal transplantation: indications and techniques. Curr Opin Ophthalmol. 2014;25:300.

2. Zirm EK. Eine erfolgreiche totale Keratoplastik [A successful total keratoplasty]. 1906. Refract Corneal Surg. 1989;5:258.
3. Darlington JK, Adrean SD, Schwab IR. Trends of penetrating keratoplasty in the United States from 1980 to 2004. Ophthalmology. 2006; 113:2171.

4. Ghosheh FR, Cremona F, Ayres BD, et al. Indications for penetrating keratoplasty and associated procedures, 2001-2005. Eye Contact Lens. 2008;34:211.

5. Dorrepaal SJ, Cao KY, Slomovic AR. Indications for penetrating keratoplasty in a tertiary referral centre in Canada, 1996-2004. Can J Ophthalmol. 2007;42:244.

6. Boimer CB, Lee K, Sharpen L, Mashour RS, Slomovic AR. Evolving surgical techniques of and indications for corneal transplantation in Ontario from 2000 to 2009. Can J Ophthalmol. 2011;46:360.

7. Zhang AQ, Rubenstein D, Price AJ, et al. Evolving surgical techniques of and indications for corneal transplantation in Ontario: 2000-2012. Can J Ophthalmol. 2013;48:153.

8. Kanavi MR, Javadi MA, Sanagoo M. Indications for penetrating keratoplasty in Iran. Cornea. 2007;26:561.

9. Zare M, Javadi MA, Einollahi B, et al. Indications for corneal transplantation at a tertiary referral center in Tehran. J Ophthalmic Vis Res. 2010;5:82.

10. Cunningham WJ, Brookes NH, Twohill HC, Pendergrast DGC, Stewart JM, McGhee CNJ. Trends in the distribution of donor corneal tissue and indications for corneal transplantation: the New Zealand National Eye Bank Study 2000-2009. Clin Experiment Ophthalmol. 2012;40:141.

11. Yaholom C, Mechoulam H, Solomon A, Raiskup FD, Peer J, Frucht-Pery J. Forty years of changing indications in penetrating keratoplasty in Israel. Cornea. 2005;24:256.

12. Dasar L, Pujar C, Gill KS, Patil M, Salagar M. Indications of penetrating keratoplasty in Southern India. J Clin Diagn Res. 2013;7:2505.

13. Pan QP, Li X, Gu Y. Indications and outcomes of penetrating keratoplasty in a tertiary hospital in the developing world. Clin Experiment Ophthalmol. 2012;40:232.

14. Xie L, Song Z, Zhao J, Shi W, Wang F. Indications for penetrating keratoplasty in North China. Cornea. 2007;20:1070.

15. Rahman I, Carley F, Hillarby C, Brahma A, Tullo AB. Penetrating keratoplasty: indications, outcomes, and complications. Eye. 2009;23:1288.

16. Siganos CS, Tsiklis NS, Miltsakakis DG, et al. Changing indications for penetrating keratoplasty in Greece, 1982-2006: multicenter study. Cornea. 2010;29:372.

17. Wang J, Xie L, Song X, Zhao J. Trends in the indications for penetrating keratoplasty in Shandong, 2005-2010. Int J Ophthalmol. 2011;4:492.

18. Keenan T, Jones M, Rushton S, Carley FM. Trends in the indications for corneal graft surgery in the United Kingdom. Arch Ophthalmol. 2012;130:621.

19. Galvis V, Tello A, Jose Gomez A, Rangel CM, Prada AM, Camacho PA. Corneal transplantation at an Ophthalmological Referral Center in Colombia: indications and techniques (2004-2011). Open Ophthalmol J. 2013;7:30.

20. Ting DSJ, Sau CY, Srinivasan S, Ramaesh K, Mantry S, Roberts F. Changing trends in keratoplasty in the West of Scotland: a 10-year review. Br J Ophthalmol. 2012;96:405.

21. Wang J, Hasenfus A, Schirra F, Bohle RM, Seitz B, Szentmary N. Changing indications for penetrating keratoplasty in Homburg/Saar from 2001 to 2010-histopathology of 1,200 corneal buttons. Graefes Arch Clin Exp Ophthalmol. 2013;251:797.

22. Tan JCH, Holland SP, Dubord PJ, Moloney G, McCarthy M, Yeung SN. Evolving indications for and trends in keratoplasty in British Columbia, Canada, from 2001 to 2011: a 10-year review. Cornea. 2014;33:252.

23. Al-Towerki A, Gonnah E, Al-Rajhi A, Wagoner MD. Changing indications for corneal transplantation at the King Khaled Eye Specialist Hospital (1983-2002). Cornea. 2004;23:584.

24. Price FW, Price MO. Adult keratoplasty: has the prognosis improved in the last 25 years? Int Ophthalmol. 2008;28:141. 
Clinical Ophthalmology

\section{Publish your work in this journal}

Clinical Ophthalmology is an international, peer-reviewed journal covering all subspecialties within ophthalmology. Key topics include: Optometry; Visual science; Pharmacology and drug therapy in eye diseases; Basic Sciences; Primary and Secondary eye care; Patien Safety and Quality of Care Improvements. This journal is indexed on

Submit your manuscript here: http://www.dovepress.com/clinical-ophthalmology-journal

PubMed Central and CAS, and is the official journal of The Society of Clinical Ophthalmology (SCO). The manuscript management system is completely online and includes a very quick and fair peer-review system, which is all easy to use. Visit http://www.dovepress.com/ testimonials.php to read real quotes from published authors. 